\title{
Copper Oxide Nanoparticles and Bulk Particles Stress Induced Cytological and Physiological Responses of Vicia Faba L.
}

\section{Vaibhav Kumar}

University of Lucknow

Adiba Khan

University of Lucknow

Alka Srivastava

University of Lucknow

Praveen Chandra Verma

National Botanical Research Institute CSIR

Gauri Saxena ( $\nabla$ gaurigupta72@yahoo.com )

University of Lucknow, Lucknow

\section{Research Article}

Keywords: CuO nanoparticle, Cytogenotoxicity, Mitotic index, Chromosomal abnormality, Micronuclei, Antioxidant enzyme

Posted Date: June 14th, 2021

DOI: https://doi.org/10.21203/rs.3.rs-575953/v1

License: (c) (i) This work is licensed under a Creative Commons Attribution 4.0 International License. Read Full License 


\section{Abstract}

CuO nanoparticles (NPs) and their bulk counter parts are being utilized in various industrial preparations. The progressive increase in the use of CuO NPs and bulk particles (BPs) eventually ends up in the environment, causing potential hazard to biota and imbalance in the abiotic components. In order to elucidate the toxic impact of CuO NPs and BPs, plant seedlings of Vicia faba var. Pusa Sumit were exposed to 20-100 mg L $\nabla^{1}$ of CuO NPs and BPs along with a control set up. Root tips and leaf tissues of plant seedlings were used to perform genotoxic and biochemical assays, respectively. Cytological preparations were used to screen mitotic indices (MI), micronuclei and chromosomal abnormalities (CAs). CuO NPs treatment led to $24.1 \%$ reduction in MI and $7.9 \%$ increase in CAs while BPs treatment reduced MI by $12.7 \%$ and raised CAs by $4.3 \%$ only. Bio-uptake of CuO NPs and BPs in the plant tissues is the key cause of oxidative stress. It triggered significant changes in lipid peroxidation and other biochemical parameters including enzymatic (peroxidase, superoxide dismutase, catalase, glutathione s-transferase and glutathione reductase) and non-enzymatic (photosynthetic pigments and proline content) components of antioxidant system in treated plant seedlings. In this study, CuO NPs caused $49.1 \%$ to $96.7 \%$ enhanced activity of antioxidant enzymes as compared to BPs. These findings revealed that $\mathrm{CuO}$ NPs were more toxic to plants than their counter BPs.

\section{Introduction}

Particles with at least one dimension less than $100 \mathrm{~nm}$ are called nanoparticles (NPs) (Auffan et al. 2009; Vert et al. 2012) and their use as such or as specifically engineered nanostructured materials has led to advances in the fields of energy, medicine, cosmetics, agriculture, biotechnology, remediation of environment and industry (Xia et al. 2013; Stephenson and Houbler 2015, Vaziri et al. 2017; Klębowski et al. 2018; Prajitha et al. 2019; Itani et al. 2020; Ziental et al. 2020). Fabrication of NPs intensifies their physicochemical properties and makes them different from its bulk particles (BPs) due to which NPs could be more toxic than their bulk counterparts (Radad et al. 2012; Rastogi et al. 2017). Extensive use of NPs and BPs has finally led to their improper disposal, adversely affecting the environment. As a result, all biological systems possibly get exposed to their toxicity (Kahru and Dubourguier 2010; Loza et al. 2014; Chichiriccò and Poma 2015; Sengul and Asmatulu 2020). Since NPs are small in size, they can easily penetrate the biological barriers, harming the physical and genomic integrity that may further result in physiological and biochemical alterations in living systems (Wen et al. 2009; Patlolla et al. 2012). Keeping in mind the hazardous impact of NPs, there is need to comprehensively understand the action and behavior of NPs in the environment and within biological systems (Maynard 2007), because reactivity (and also aggregation state) of NPs varies according to environment. Several studies have reported toxicity of nanomaterials in bacteria and animals but data are scarce on cytogenotoxic potential of NPs in higher plants (Castiglione et al. 2011; Patlolla et al. 2012; Demir et al. 2014; Pakrashi et al. 2014; Jośko et al. 2017; Mangalampalli et al. 2017; Ganguly et al. 2018; Wan et al. 2019).

CuO NPs have brought a commercial revolution due to their extensive use in electronics, optics, energy, gas sensors, antimicrobial agents, catalysis and in cross coupling reactions (Jammi et al. 2009; Song et 
al. 2016; Ochoa et al. 2017, Nasrollahi et al. 2019). In the last decade, CuO NPs production has been estimated in hundreds of tons (Keller et al. 2013), much of which is finally ended up in the environment. Besides, NPs are also being utilized in the agricultural system as nano fertilizers and nano pesticide formulations to protect the crop plants from various pests and pathogens (Lazareva and keller 2014; Kah 2015; Servin et al. 2015; Rastogi et al. 2019; Zhao et al. 2020). Consequently, NPs are expected to enter the biological systems and interact with their subcellular compartments resulting in overproduction of reactive oxygen species (ROS) causing oxidative stress, genotoxicity, cytotoxicity, chlorosis and ultimately growth inhibition (Nair and Chung 2014). To maintain cellular redox status, plants operate several protective strategies. The antioxidant system is one of the protective mechanism, involving both enzymatic and non-enzymatic components. The enzymatic component includes various ROS scavengers such as peroxidase (POD), superoxide dismutase (SOD), glutathione s-transferase (GST), glutathione reductase (GR), catalase (CAT) etc. The non-enzymatic component includes ascorbate, glutathione, proline (osmolyte), chlorophyll, carotenoids, etc. which are crucial for growth and confer tolerance against oxidative stress in plants (Gill and Tuteja 2010; Li et al. 2018; Sharma et al. 2020).

Several plant bioassays have been suggested to elucidate the toxicological effects of NPs and BPs. $V$. faba is one model plant to evaluate genotoxic effect of environmental contaminants due to its sensitive mitotic dynamics and large size of chromosomes (Lutterbeck et al. 2015; Silveria et al. 2017). This study has been conceptualized to assess the toxicity potential of CuO NPs and BPs using $V$. faba test system through genotoxic (MI, CAs, and micronuclei) and biochemical (POD, SOD, CAT, GST, GR, lipid peroxidation, proline content, and photosynthetic pigments) assays. Bio-uptake studies of nanomaterials that are important to assess their internalization in different plant tissues have also been undertaken in this study. Though there are several reports on cytogenotoxic assessment of environmental contaminants in plants, this is the first of its kind to show the cytological and physiological effects of CuO NPs in V. faba.

\section{Materials And Methods}

\section{CuO NPs and BPs and their characterization}

Nanopowder of CuO was provided by Sigma-Aldrich (now Merck). Its primary particle size is $<50 \mathrm{~nm}$, purity is $99.9 \%$ based on trace metals. CuO BPs were procured from HiMedia with $98 \%$ purity (These specifications details are as data provided by the manufacturer). For the preparation of mono-suspension of NPs and BPs, a weighed amount of chemicals was directly put in deionized water separately and subjected to sonication ( $1 \mathrm{Amp}, 20 \mathrm{kHz}$ ) for 30 minutes.

Characterization of CuO NPs and BPs was done through a scanning electron microscope (SEM) and dynamic light scattering (DLS) for size, morphology, state of dispersion, size distribution and for stability concern of chemical, the zeta potential was recorded. For size determination, 100 particles were measured from different fields of SEM view and images showing the morphology of the particles. The mean hydrodynamic diameter (MHD) of the particles and polydispersity index ( $\mathrm{Pdl}$ ) was recorded through 
DLS using a zetasizer (Malvern Instruments Ltd). The Pdl was used to measure the heterogeneity or size range in a sample and numerical value ranged from 0 to 1 (monodispersion to ploydispersion state of particles).

Test system and treatment

Seeds of V. faba var. Pusa Sumit obtained from National seed corporation, Lucknow were used. They were washed four to five times in distilled water followed by deionized water and then soaked in deionized water for 24 hours. They were finally rinsed and kept on moist blotting sheets in Petri plates. After two to three days, when roots became 2 to $3 \mathrm{~cm}$ long their tips were removed for the proliferation of secondary roots. After 2 days when secondary roots emerged they were exposed to the graded concentration of CuO NPs and BPs $\left(20,40,60,80\right.$ and $\left.100 \mathrm{mg} \mathrm{L} \nabla^{1}\right)$ including control in the form of deionized water alone. After 6 hours exposure to CuO NPs and BPs, the roots were fixed for cytological studies.

In another set of experiments, growing seedlings were exposed to same concentrations of chemicals and for similar duration as mentioned above. After treatment seedlings were transferred to fresh petri plates and allowed to grow for 15 days till the development of the first pair of leaves. These leaves were utilized for biochemical analysis and data were recorded for morphological parameters. All the experiments were conducted in triplicate.

Fixing of roots and analysis of genotoxicity

Carnoy's fluid (3:1 preparation of ethyl alcohol and acetic acid respectively) was utilized for fixing secondary root tips. After 24 hours root tips were transferred to $70 \%$ alcohol and stored under refrigeration at $4{ }^{\circ} \mathrm{C}$. Cytological preparations were carried out according to the protocol developed by Sharma and Sharma (1980). Cytological observations were recorded using temporary slide preparations to screen mitotic activity/(MI), micronuclei, and several CAs. Approximately 1000 cells from at least 10 well smeared microscopic fields out of 20 fields captured from different root meristems preparation per treatment were screened at $400 \mathrm{x}$ under the light microscope (Magnus MLX-TR Plus) (Khan et al. 2021). $\mathrm{MI}$ percentage, CAs and cells with micronuclei were calculated in reference to total number of cells in a microscopic field.

Mitotic Index (MI) $\%=\frac{\text { Total no. of dividing cells }}{\text { Total no. of cells observed in field }} \times 100$

$$
\text { Abnormality } \%=\frac{\text { No. of abnormal cells }}{\text { Total no. of cells observed }} \times 100
$$

Morphological parameters 
Data for relevant parameters like root length and shoot length were recorded for control and treated seedlings after the stipulated time. Phytotoxicity was calculated according to following formula (Chou et al. 1978).

$$
\text { Percentage of phytotoxicity }=\frac{\text { Radicle length of control }- \text { Radicle length of treatment }}{\text { Radicle length of control }} \times 100
$$

Photosynthetic pigment estimation

$100 \mathrm{mg}$ fresh leaf tissue was crushed in $80 \%$ acetone for the assessment of photosynthetic pigments including chlorophyll and carotenoids (Arnon 1949). The crude mixture was centrifuged at $6000 \mathrm{xg}$ for $10 \mathrm{~min}$. The supernatant was used to record absorbance at 645,652 , and $663 \mathrm{~nm}$ for chlorophyll and 480 and $510 \mathrm{~nm}$ for carotenoids estimation using a spectrophotometer (Cary 5000, Agilent Technologies)

\section{Estimation of lipid peroxidation}

Lipid peroxidation was assayed according to the protocol of Heath and Packer (1968) with certain modifications. $200 \mathrm{mg}$ of fresh leaf tissue was homogenized in $3 \mathrm{ml}$ of $0.1 \%$ trichloroacetic acid (TCA) and centrifuged at $10000 \times \mathrm{g}$ for $15 \mathrm{~min}$ at $4^{\circ} \mathrm{C} .1 \mathrm{ml}$ of supernatant was mixed with $4 \mathrm{ml}$ of $20 \%$ TCA containing $0.5 \%$ TBA (thiobarbituric acid) and heated in a water bath at $90^{\circ} \mathrm{C}$ for $30 \mathrm{~min}$ to develop MDA adduct with TBA. After heating, the reaction mixture was ice-cooled for $10 \mathrm{~min}$ and subjected to centrifugation at $15000 \mathrm{xg}$ for $5 \mathrm{~min}$. The supernatant was used to record absorbance at $532 \mathrm{~nm}$ with the subtraction of non-specific absorbance at $600 \mathrm{~nm}$. MDA content was calculated using the extinction coefficient $(\Downarrow)$ of $155 \mathrm{mM}^{-1} \mathrm{~cm}^{-1}$.

\section{Estimation of proline content}

Proline (osmoprotectant) estimation was done according to Bates et al. (1973) with few modifications in the protocol. $200 \mathrm{mg}$ of leaf tissue from control and treated plants were ground in $5 \mathrm{ml}$ solution of $3 \%$ sulphosalicylic acid and the crude mixture was centrifuged at $10000 \mathrm{xg}$ for $10 \mathrm{~min} .2 \mathrm{ml}$ of supernatant was taken in a test tube and mixed with $2 \mathrm{ml}$ of glacial acetic acid and ninhydrin each. Reaction tubes were heated in the water bath at $96^{\circ} \mathrm{C}$ for one hour. Tubes were allowed to cool down in ice to terminate the reaction. Samples were extracted with toluene and absorbance of chromophore containing the mixture was recorded at $520 \mathrm{~nm}$. Amount of proline was calculated against its standard curve.

\section{Antioxidant enzyme assays}

Catalase estimation was done as described by Euler and Josephson (1927). $150 \mathrm{mg}$ of fresh leaf tissue was homogenized in $6 \mathrm{ml}$ of distilled water. The crushed sample was centrifuged at $10000 \mathrm{xg}$ for $10 \mathrm{~min}$. $1 \mathrm{ml}$ enzyme extract was mixed with sub-mixture $(0.1 \mathrm{M}$ phosphate buffer of potassium $\mathrm{pH} 7.0$ and $10 \%$ $\mathrm{H}_{2} \mathrm{O}_{2}$ ) in a reaction container. Blank was maintained without enzyme extract. After 5 minutes, $5 \mathrm{ml}$ of $2 \mathrm{~N}$ 
$\mathrm{H}_{2} \mathrm{SO}_{4}$ was added to the reaction container to terminate the reaction. The reaction mixture was titrated against $0.1 \mathrm{~N} \mathrm{KMnO}_{4}$.

Peroxidase assay was based on p-phenylenediamine oxidation using $\mathrm{H}_{2} \mathrm{O}_{2}$ as an oxidant (Luck 1963). $50 \mathrm{mg}$ of fresh leaf tissue was homogenized in $10 \mathrm{ml}$ of extraction buffer and the homogenate was centrifuged at $10000 \mathrm{xg}$ for $10 \mathrm{~min}$. The reaction mixture contained $5 \mathrm{ml}$ of $0.1 \mathrm{M}$ potassium phosphate buffer (pH 6.8), $1 \mathrm{ml} \mathrm{p-phenylenediamine} \mathrm{(0.5 \% ),} 1 \mathrm{ml}$ enzyme extract and $1 \mathrm{ml} \mathrm{H}_{2} \mathrm{O}_{2}(0.01 \%) .2 \mathrm{ml}$ of $5 \mathrm{~N}$ $\mathrm{H}_{2} \mathrm{SO}_{4}$ was used as reaction stopper. Reaction tubes were cooled down in ice for $20 \mathrm{~min}$. Absorbance was recorded at $485 \mathrm{~nm}$.

Superoxide dismutase assessment was done using the protocol based on its ability to inhibit the reduction of NBT (nitroblue tetrazolium) (Beauchamp and Firdovich 1971). $100 \mathrm{mg}$ of fresh leaf tissue was extracted in a grinding medium and the crude extract was centrifuged at $5000 \mathrm{x} \mathrm{g}$ for $10 \mathrm{~min} .3 \mathrm{ml}$ of reaction mixture contained $50 \mathrm{mM}$ phosphate buffer ( $\mathrm{pH}$ 7.8), $0.1 \mathrm{mM}$ EDTA, $10 \mathrm{mM}$ methionine, 0.07 $\mathrm{mM} \mathrm{NBT}, 3 \mu \mathrm{M}$ riboflavin and $0.5 \mathrm{ml}$ enzyme extract. Sample tubes were irradiated in light for $20 \mathrm{~min}$ (appearance blue colour). Blanks were maintained in dark. The absorbance of radiated and non-radiated samples was recorded at $560 \mathrm{~nm}$.

Glutathione s-transferase assessment was based on its ability to catalyze the conjugation of glutathione (GSH) to 1-chloro-2,4-dinitrobenzene (CDNB) as described by Habig et al. (1974). Its activity was determined in $3 \mathrm{ml}$ reaction volume containing $100 \mathrm{mM}$ phosphate buffer (pH 6.5), $1 \mathrm{mM} \mathrm{GSH}, 1 \mathrm{mM}$ CDNB and $100 \mu \mathrm{l}$ of enzyme extract. The reaction was started by adding CDNB. The change in absorbance of the reaction sample at $340 \mathrm{~nm}$ was recorded for $5 \mathrm{~min}\left(\mathbb{\nabla}=9.6 \mathrm{mM}^{-1} \mathrm{~cm}^{-1}\right)$. The protein content of leaves was determined according to Bradford (1976).

Glutathione reductase was assessed in terms of glutathione based oxidation of NADPH according to Carlberg and Mannervik (1985). $1 \mathrm{ml}$ assay mixture contained $200 \mathrm{mM}$ phosphate buffer (pH 7), $2 \mathrm{mM}$ EDTA, 20 mM GSSG, 2 mM NADPH and $100 \mu$ enzyme extract. The reaction was started by adding $\mathrm{NADPH}$. The decrease in absorbance of the reaction sample at $340 \mathrm{~nm}$ was recorded for $5 \mathrm{~min}(\mathbb{Z}=6.22$ $\left.\mathrm{mM}^{-1} \mathrm{~cm}^{-1}\right)$.

Bio-uptake of CuO NPs and BPs

The quantity of CuO NPs and BPs internalized by $V$. faba was determined according to Pakrashi et al. (2014). The treated plant materials were washed with deionized water and were oven-dried at $60^{\circ} \mathrm{C}$ for 24 hours. The tissue samples (roots and leaves) were crushed separately in sterile mortar and pestle. The powdered samples were subjected to digestion in concentrated $\mathrm{HNO}_{3}$ and soluble parts were filtered through 0.25 micrometer membrane filter. The amount of NPs and BPs internalized into the tissues was determined by ICP-OES (Inductively coupled plasma optical emission spectroscopy; Perkin Elmer Optima 5300 DV, USA).

Statistical analysis 
Results of all the observations were represented by mean values and standard error of the mean. Mean values were compared through one-way Analysis of Variance (ANOVA) followed by Duncan's multiple range test $(\mathrm{DMRT})$ at $\mathrm{P} \leq 0.05$.

\section{Results}

Characterization of CuO NPs and BPs

SEM images showed more or less circular crystalline structure of NPs and BPs. The sizes of the CuO NPs and BPs obtained by SEM analysis were $49 \pm 3.4 \mathrm{~nm}$ and $1 \pm 0.2 \mu \mathrm{m}$ respectively (Supplementary Fig. 1). The zeta potential value and Pdl of CuO NPs in deionized water suspension analyzed by DLS were -30.6 $\mathrm{mV}$ and 0.134 respectively and these values for CuO BPs were $-33.4 \mathrm{mV}$ and 0.121 respectively. The MHDs of NPs were $191 \pm 2.3,193 \pm 3.1,190 \pm 3.4,192 \pm 4.1$, and $195 \pm 4.1 \mathrm{~nm}$ at 0 hours for 20, 40,60, 80 , and $100 \mathrm{mg} \mathrm{L} \nabla^{1}$ concentrations respectively. In terms of hydrodynamic stability of dispersions, MHDs of NPs after six hours of treatment were found to be $192 \pm 3.8,192 \pm 4.3,194 \pm 3.7,196 \pm 2.9$, and $199 \pm$ $4.2 \mathrm{~nm}$ for chemical suspensions of $20,40,60,80$, and $100 \mathrm{mg} \mathrm{L}^{1}$ respectively. The MHDs of particles at 0 and 6 hour did not show any significant statistical difference. This means that particles did not initiate agglomeration during the treatment period. Thus, dispersions were considered stable during the treatment period.

Microscopic analysis

A detailed microscopic observation of smears prepared from treated secondary root tips of $V$. faba var. Pusa Sumit provided an overview of cytogenotoxic potential of CuO NPs and BPs. Different genetic endpoints like MI, CAs, and micronuclei were analyzed in root meristems exposed to graded concentrations of NPs and BPs suspensions viz. 20, 40, 60, 80, and $100 \mathrm{mg} \mathrm{L}^{1}{ }^{1}$ including control. Each index showed a dose-dependent correlation to chemical exposure. The correlation coefficients (r-value) of MI were found to be -0.99 and -0.95 against the treatment of $\mathrm{CuO}$ NPs and BPs respectively. Maximum MI was recorded in control, i.e., $34.0 \pm 0.62$ and it reduced gradually in treated root cells at 20, 40, 60, 80, and $100 \mathrm{mg} L \nabla^{1}$ concentrations. At $100 \mathrm{mg} L \nabla^{1}$ exposure, MI was minimum and found to be $9.9 \pm 0.57$ (NPs) and $21.3 \pm 0.78$ (BPs) (Table 1 and Fig. 1A). Reduction in MI with increasing concentration of CuO NPs and BPs was found statistically significant $(p \leq 0.05)$.

The microscopic studies on mitotic phases in cells of secondary root meristems of $V$. faba revealed several CAs including stickiness, fragmentation, diagonal anaphases, precocious chromosomes, laggards, bridges, C-metaphase, spindle deformities, clumping, and micronuclei formation (Fig. 5). The correlation coefficient (r-value) of CAs was found to be 0.99 in both CuO NPs and BPs treated roots. Average percentage of CAs were minimum at $20 \mathrm{mg} \mathrm{L} \mathbb{1}^{1}$ concentration i.e., $1.93 \pm 0.33$ (NPs) and $0.89 \pm$ 0.23 (BPs). The percentage of CAs increased with increasing concentrations of chemicals and reached maximum at $100 \mathrm{mg} \mathrm{L} \mathbb{1}^{1}$ i.e., $7.85 \pm 0.54$ (NPs) and $4.3 \pm 0.33$ (BPs) (Table 2 and Fig. 1B). The increase in the occurrence of these abnormalities was found significant in statistical reference ( $p \leq 0.05)$. At $20 \mathrm{mg}$ 
$L \bigotimes^{1}$ exposure of CuO NPs, several aberrations viz. chromosome break, disturbance in the organization of metaphase chromosomes and movement of chromosomes at anaphase/spindle disturbance, diagonal anaphases, and micronuclei were observed. However, frequency of these aberrations was low in comparison to that observed at higher doses of chemicals. Additionally, several other aberrations such as fragmentation, stickiness, clumping of chromosomes, precocious chromosomes, bridges, laggards, and C- metaphase were observed at 40 and $60 \mathrm{mg} \mathrm{L} \mathbb{X}^{1}$ exposure. At the highest dose exposure of 80 and 100 $\mathrm{mg} \mathrm{L} \otimes^{1}$, the average frequency of aberrations was much high and interestingly, multiple chromosomal aberrations like fragments, bridges, and laggards were seen in a single cell. However, the frequency of aberrations was higher in CuO NPs treatment as compared to BPs. The frequency of each aberration at all concentrations of CuO NPs (Fig. 1C) and BPs (Supplementary Fig. 3) has also been recorded during experiment.

Presence of micronuclei in cells was also dose-dependent; being ( $r$-value $=0.99)$ with CuO NPs and $(r-$ value $=0.98$ ) in case of CuO BPs both being statistically significant. The average formation of micronuclei was $1.13 \pm 0.24,2.20 \pm 0.36,3.66 \pm 0.34,4.98 \pm 0.38,6.15 \pm 0.59$ in NPs treatment and 0.48 $\pm 0.21,0.82 \pm 0.29,1.34 \pm 0.31,2.13 \pm 0.28,3.07 \pm 0.35$ in BPs treatment at 20,40,60,80, $100 \mathrm{mg} \mathrm{L} \mathbb{1}^{1}$ concentration of each respectively (Fig. 1D).

Morphological analysis

Plants exposed to CuO NPs showed a marked reduction in root and shoot lengths and leading to increase in phytotoxicity percentage. However, BPs stress did not show any significant reduction in seedling growth at an initial concentration (20 mg Lه $\otimes^{1}$ ), and its effects were less severe than that of NPs. Upon application of $100 \mathrm{mg} \mathrm{L{ } ^ { 1 }}$ of CuO NPs and BPs maximum reduction of 3.72 and 1.79 fold in root and 3.29 and 1.64 fold in shoot lengths was recorded over control (Fig. 1E, 1F \& supplementary Fig. 2). Phytotoxicity percentage was observed 73.15 and 44.12 , respectively at concentration of $100 \mathrm{mg}$ $\mathrm{L} \rrbracket^{1}$ (supplementary Fig. 4).

Photosynthetic pigments

The content of photosynthetic pigments including chlorophyll and carotenoids significantly decreased under NPs and BPs stress. Plants exposed to NPs had a lower amount of pigments than plants under bulk particle stress. The total decline of 2.99 fold in chlorophyll and 3.93 fold in carotenoids content was recorded over control under NPs stress. While this decline was 1.56 fold and 2.03 fold under BPs stress (Fig. 2A and 2B). The amount of photopigments exhibited a similar trend and decreased with increasing concentration of CuO NPs treatment.

Malondialdehyde and Proline contents

The degree of lipid peroxidation in leaves was recorded in terms of MDA content. It significantly increased throughout the whole range of $\mathrm{CuO}$ NPs and BPs concentrations. The highest MDA content was recorded at $100 \mathrm{mg} \mathrm{L} \mathbb{X}^{1}$ of CuO NPs and BPs, i.e., 2.84 and 2.18 fold over control respectively (Fig. 2C). Moreover, 
significant alteration in proline content was also recorded in treated leaves. In case of CuO NPs treated

plants, maximum accumulation of proline content was recorded at $80 \mathrm{mg} \mathrm{L} \rrbracket^{1}$ concentration, i.e., 2.43 fold over control. While in case of CuO BPs treated plants proline content increased to 1.9 fold over control (Fig. 2D).

Activities of antioxidant enzymes

Among the various antioxidant enzymes assessed in our study, CAT, POD and SOD showed more or less similar trend of activity while GST and GR varied. The activities of these antioxidant enzymes altered significantly and POD activity was found to be more affected in plants leaves under CuO NPs stress. An increase of 3.23 fold in CAT, 3.95 fold in POD and 2.59 fold in SOD activity was recorded over control in NPs exposed leaves (Fig. 3A, 3B and 3C). The enzymatic activity exhibited dose-dependent increase up to

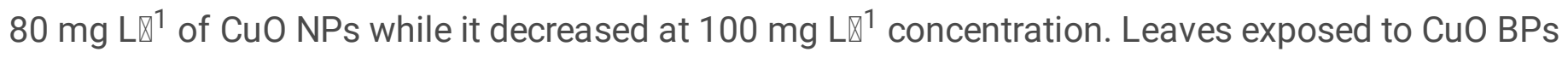
showed increased activity of these enzymes in each concentration of chemical and the highest recorded increment was 2.43 fold in CAT, 2.98 fold in POD and 2.03 fold in SOD activity as compared control (Fig. $3 \mathrm{~A}, 3 \mathrm{~B}$ and $3 \mathrm{C})$.

Activities of GST and GR in plant leaves altered significantly at lower concentrations of CuO NPs and the highest activity was recorded at $60 \mathrm{mg} \mathrm{L} \otimes^{1} \mathrm{NPs}$. Further raising their concentrations reduced GST and GR activities. At $100 \mathrm{mg} \mathrm{L} \mathbb{1}^{1}$, GST activity was lower than control, however, the difference was not significant in statistical reference. Under BPs stress, GST and GR activities were less affected at initial concentrations. At $100 \mathrm{mg} \mathrm{L} \mathbb{1}^{1}$, maximum activity of GST (1.69 fold) and GR (1.51 fold) was recorded over control (Fig. 3D and 3E).

Bio-uptake of CuO NPs and BPs

The ICP-OES analysis showed dose-dependent increase in the amount of CuO NPs and BPs internalized into the plant tissues. For CuO NPs, internalized Cu was $2.79 \pm 0.36,7.44 \pm 0.58,13.5 \pm 0.78,18.45 \pm$ 0.82 , and $22.72 \pm 0.58 \mathrm{mg} \mathrm{L} \rrbracket^{1}$ in roots and $1.03 \pm 0.08,2.06 \pm 0.2,3.57 \pm 0.24,5.53 \pm 0.32$, and $7.34 \pm$ $0.33 \mathrm{mg} \mathrm{L} \otimes^{1}$ in leaves at 20,40,60,80, and $100 \mathrm{mg} \mathrm{L} \otimes^{1}$ respectively (Fig. $4 \mathrm{~A}$ ). However, in the case of CuO BPs, internalized Cu was $1.31 \pm 0.1,2.65 \pm 0.31,4.43 \pm 0.7,6.28 \pm 0.45$, and $7.62 \pm 0.45 \mathrm{mg} \mathrm{L} \mathbb{\nabla}^{1}$ in roots and $0.56 \pm 0.07,0.88 \pm 0.15,1.79 \pm 0.27,2.71 \pm 0.22$, and $3.64 \pm 0.18 \mathrm{mg} \mathrm{L}^{1}{ }^{1}$ in leaves at $20,40,60,80$,

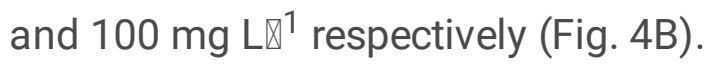

\section{Discussion}

Growing variation and utilization of industrial products has become possible due to the incorporation of NPs during the manufacturing process. NPs are also playing a progressive role in medical aspect (Grigore et al. 2016). But improper disposal management of nanomaterials has raised concerns about environmental safety (Colvin 2003, Bystrzejewska-Piotrowska et al. 2009; Oliveira et al. 2019). Despite shaping a new era of nanotechnology, the potential toxicity of CuO NPs to the ecosystem and its 
constituents are yet to be thoroughly elucidated. This experimental study was undertaken to assess the toxicity potential of CuO NPs and BPs in an economically important pulse crop $\mathrm{V}$. faba.

$V$. faba is an established test system for cytological studies to assess the toxic potential of environmental contaminants. Exposure of secondary root tips to varying concentrations of CuO NPs and BPs affected $\mathrm{Ml}$ and caused CAs in dividing cells. Mean MI exhibited a negative correlation while the frequency of CAs was positively correlated with increasing concentrations of NPs and BPs. After crossing biological barriers, how NPs react with cellular integrities is still unknown (Nair et al. 2010; Miralles et al 2012; Magdolenova et al. 2014). Reduced MI percentage could be due to disturbed progression of cells from one phase to other (like G1-S and S-M) of cell cycle on exposure to CuO NPs. NPs may access DNA either through nuclear pores or during dissolution of the nuclear membrane in cells undergoing mitotic division (Liang et al. 2008; Barillet et al. 2010). The Ml reflects the proliferating capacity of a zone where cells actively divide however, upon exposure to a toxic chemical it decreases indicating cytotoxicity (Liu and Yi 2007; Jing-Jing 2011).

CuO NPs and BPs exposure revealed various CAs in root tips of $V$. faba and frequency of aberration increased with exposure to increasing concentration of chemical. Any chemical that drastically affects the genomic integrity of a cell is called genotoxin. Induction of CAs (clastogenic/mutagenic effects) in root meristematic cells of $V$. faba on exposure to CuO NPs proves the fact that they too can be categorized as genotoxin. Among the various observed CAs, fragmentation, precocious movement, and clumping of chromosomes were the most prevalent aberrations. However, multiple CAs like chromosome bridges, laggards and breaks, were also observed in single cells at higher concentrations. The underlying mechanism responsible for causing genetic damage is an interesting and relevant area of research and would help to determine whether the effect of NPs on DNA is general or nanospecific. NPs may cause genotoxicity either directly through interaction with nucleic acids or they may interfere with protein assembly during DNA replication (Carmona et al. 2018) or damage caused by reactive oxygen species generation (Kisin et al. 2007). There may be several attributions to the increased frequency of aberrations. These aberrations come mainly from DNA breaks and chromatin damage (laggards, fragments), deformities of spindle apparatus (c-mitosis, disturbed anaphase, precocious chromosomes, bridges), and chromatin disorganization (stickiness and clumping) (Castiglione et al. 2011; Khan and Ansari 2018). Chromosome gaps and breaks are an issue of debate as they are usually not distinguished easily and so sometimes regarded as one and the same kind of aberration (Brøgger 1982; Savage 2004). Gaps are the result of the loss of chromatin or lack of only protein part from chromatin fiber (Topaktas et al. 1993) while breaks are produced when double-strand breaks occur at DNA level in cells and they do not undergo repair process. Lagging chromosomes result from miss-matched attachment of spindle microtubules to centromere kinetochore (merotelic attachment). Because of this merotelic attachment, particular chromatid fails to separate to segregating mass and results as lagging chromosome (Cimini et al. 2002; Redli et al. 2016). The occurrence of anaphase bridges involves the fusion of sister chromatids through their telomeres and this fusion restricts proper separation of chromatin material towards each pole (Chan and Hickson 2011). Stickiness in the chromosome at various mitotic phases is still being probed (Tatum and Rayburn 2006). It could be due to interference in proteins involved in the organization 
of chromatin fibers (Gaulden 1987; Khan et al. 2009). The degree of stickiness may be slight, moderate, or severe. Intense stickiness results in clumping of chromosomes.

Presence of micronuclei in cells also indicated genotoxicity caused due to CuO NPs and BPs. The actual mechanism of how NPs induce micronuclei is still unknown. However, micronucleus formation occurs when acentric fragments or lagging chromosomes are excluded from total genetic complement during mitosis. The nuclear membrane organizes around the excluded part and resembles the nucleus proper (Fenech et al. 2011). Our findings of mito-depression, micronuclei induction and increased CAs on exposure to NPs and BPs are parallel to the studies made in Vicia norbonensis and Zea mays against $\mathrm{TiO}_{2}$ NPs, $V$. faba against silver NPs and Allium cepa against $\mathrm{TiO}_{2}$ NPs (Castiglione et al. 2011; Patlolla et al. 2012; Pakrashi et al. 2014).

Morphological parameters are visible indicators of any type of physiological or biochemical changes in plants exposed to stress. In the present study, the effect of CuO NPs on seedling growth is severe than CuO BPs. Decrease in root and shoot length and increase in phytotoxicity percentage were dosedependent. Additionally, the content of photosynthetic pigments (chlorophyll and carotenoids) also decreased significantly under NPs and BPs stresses. Chlorophylls and carotenoids play a vital role in light-harvesting and ROS quenching respectively. It is known that chloroplast and mitochondria are organelles where ROS is actively produced (Hernández et al. 1993). Under NPs stress, excess ROS production causes oxidative stress either through direct interaction or by their dissolution into ions. Reduction in pigment content might be due to disruption of chloroplast membrane and disassembly of photosynthetic apparatus under oxidative stress. Our findings of growth inhibition and pigment reduction also corroborate the studies made in Arabidopsis thaliana and Pisum sativum against CuO NPs (Nair and Chung 2014; Ochoa et al. 2017). Shi et al. (2014) reported a threefold decrease of chlorophyll content in Elsholtzia splendens under hydroponic treatment of CuO NPs.

MDA is a potential biomarker to assess the degree of ROS generated oxidative damage in the form of lipid peroxidation (Hashemi 2019). In our experiment, treated plants showed an increased level of MDA content. The enhanced MDA activity might be due to the toxicological manifestation of NPs in the form of excess ROS generation. The imbalance between ROS production and its removal leads to oxidative damage of lipids in membranes. It is well known that unsaturated fatty acids of biomembranes are the main target of radicals attack. They initiate a chain reaction producing fatty acid radicals causing damage to the membrane via lipid peroxidation. Song et al. (2016) observed a similar trend of MDA activity in Lemna minor under nano-CuO stress.

Plants start accumulation of osmoprotectant as a physiological adaptation in response to abiotic stress. Proline is one of them accumulates under NPs and other metal stresses (Choudhary et al. 2007; Hashemi 2019). Approximately two-fold accumulation of proline was recorded in treated plants in this study. This increment in proline content helps plants to maintain cell osmoticum without hampering the metabolic status of cells. Its role in membrane stabilization and ROS detoxification has also been proposed (Hayat et al. 2012). However, increased proline content does not appear to be effective to protect cells from ROS 
generated oxidative damage under CuO NPs stress, as evident from enhanced MDA content in treated seedlings. In context of this study, it can be said that high proline content in plant leaves exposed to $\mathrm{CuO}$ NPs is simply a stress effect rather than being stress protectant.

Higher exposure of plants to NPs may also alter their physiological activities and lead to disturbance of ROS pool in the cellular environment (Mirzajani et al. 2013). To scavenge ROS and withstand the toxic response of contaminants, plants utilize a highly sophisticated system of detoxification i.e., antioxidant system. The sequential/simultaneous action of these antioxidant enzymes such as CAT, POD, SOD, etc. performs the cooperative function in ROS scavenging and maintaining redox status of plants (Wise 1995). Enhanced activities of CAT, POD, and SOD in V. faba plants under CuO NPs stress are an indication of elevated ROS level as well as quick activation of plants antioxidant system to combat oxidative stress. Both CAT and POD brings about scavenging of a non-radical ROS, $\mathrm{H}_{2} \mathrm{O}_{2}$, via its conversion into $\mathrm{H}_{2} \mathrm{O}$, but POD can utilize a variety of electron donor to decompose $\mathrm{H}_{2} \mathrm{O}_{2}$ and other hydroperoxides (Fryer et al.

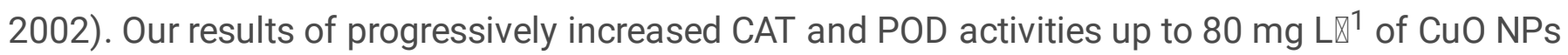
suggest that plants suffered from moderate stress. However, decreased CAT and POD activities at 100 mg L $\otimes^{1}$ represented plant's inability to control oxidative stress. Therefore, CAT and POD can be considered as sensitive biomarkers for NPs stress. Our findings are consistent with existing studies made by Dimkpa et al. (2012) in Triticum aestivum and Nekrasovaa et al. (2011) in Elodea densa under CuO Nps and Cu stress respectively.

SODs are front-line defenders of the antioxidant system as their activity is positively correlated with the amount of $\mathrm{O}_{2}{ }^{*} \otimes$ (Bowler et al. 1992). SOD catalyzes the dismutation of $\mathrm{O}_{2}{ }^{\circ} \otimes$ into $\mathrm{O}_{2}$ and $\mathrm{H}_{2} \mathrm{O}_{2}$. It contains different isozymes including Fe-SOD, Mn-SOD and Cu/Zn-SOD in subcellular compartments which catalyze the detoxification of ROS and reduce the toxic effects (Fridovich 1989). In treated plants, SOD activity increased throughout the whole range of concentration from 0 (control) to $100 \mathrm{mg} \mathrm{L \otimes}{ }^{1}$ of $\mathrm{CuO}$ NPs and BPs but the extent of effect was lesser under BPs stress. A similar trend of SOD activity was reported in Oryza sativa under nano-CuO stress (Shaw and Hossain 2013). In our experiment, treated plants showed significantly increased activity of GST and GR. GSTs are detoxification enzymes of cytosolic and microsomal compartments which help to protect cellular macromolecules (cellular integrity) from the attack of reactive electrophiles (Townsend and Tew 2003). Specifically, GSTs catalyze the conjugation of a wide range of electrophilic compounds to glutathione. Plant GSTs are mainly involved in the detoxification of contaminants and confer tolerance against stress (Dixon et al. 2010). GR is an enzyme of the oxidoreductase family and an important component of ASH-GSH cycle that sustains a high GSH/GSSG ratio. GR reduces metallic NPs into intermediates that power up ROS response. In our study, increased GR activity could be explained in two ways: ascorbate-glutathione cycle might be operating fast in order to prevent ROS generated oxidative stress or maintained the status of glutathione helps in the regular synthesis of phytochelatins involved in metabolism and clearance of contaminants (Gill et al. 2013). 
The mechanism of nanoparticle-induced oxidative stress in plants is not well known. However, the physicochemical properties of NPs themselves and cellular response such as cell-nanoparticle interaction and signaling cascades are responsible for ROS-induced damages (Manke et al. 2013). After cellular internalization, Cu metal NPs catalyze the overproduction of ROS $\left(\mathrm{O}_{2}{ }^{\cdot \otimes}\right.$ and $\left.\mathrm{OH}^{\circ}\right)$ by Fenton and HaberWeiss type reactions leading to oxidative stress phenomenon resulting in damage of proteins and nucleic acids and lipid peroxidation (Gill and Tuteja 2010). According to Huang et al. (2010), cellular integrities respond to oxidative stress via an antioxidant enzyme system upon nanoparticle exposure. Moderate oxidative stress initiates transcriptional activation of phase II antioxidant enzymes (SOD, POD, CAT, GR, etc.) via nuclear factor and mitogen-activated protein kinase cascade system. However, very high levels of oxidative stress result in structural damages of mitochondrial membrane and electron transport chain dysfunction leading to cell death. Researchers have made some consensus on the action and behavior of NPs in environment, but there are still many controversies and uncertainties that need to be further studied.

Bio-uptake or internalization of NPs is a prime cause of inducing toxicity in plants by generating oxidative stress in the cells. Few studies have revealed that the internalization of NPs causes genotoxicity in $V$. faba and Allium cepa root cells. In this study, ICP-OES analysis showed size and dose-dependent increase in the internalization of total $\mathrm{Cu}$ in plant tissues. Mangalampalli et al. (2017) found that both the uptake of NPs and BPs and their capacity to induce genotoxic effects in A. cepa roots are dose-dependent. Biouptake of $\mathrm{AgNO}_{3} \mathrm{NPs}_{\text {s }}$ has been found to cause genotoxic effects in $\mathrm{V}$. faba root cells (Patlolla et al. 2012). An experiment carried out with CuO NPs in rice demonstrated that NPs were taken up by various tissues of plants which lead to significant biochemical changes through oxidative stress in cells (Costa and Sharma 2016). Along with element analysis through spectroscopy, these reports also provide evidence of particle internalization by electron micrographs. Further internalization of NPs is more as compared to BPs. However, toxicity can also be changed due to the dissolution of CuO NPs into Cu ions during translocation. Meanwhile, during translocation, the dissolution of CuO NPs may be increased due to a decrease in $\mathrm{pH}$ and interaction with organic moieties in plant tissues and cells. Since, in this study, toxicity as evident by mito-depression, CAs, and rise in antioxidants was observed in plant tissues, CuO NPs might have translocated in the internal environment and their subsequent dissolution into $\mathrm{Cu}$ ions could result in oxidative stress.

\section{Conclusion}

This study showed that CuO NPs negatively affect the $V$. faba plant in terms of Ml, CAs, and enzymatic assays and are more toxic than their bulk counter-parts as evident from morphological parameters. Considered genetic endpoints revealed clastogenic (involving DNA damage), aneugenic, and turbagenic (without DNA damage) potential of chemicals. CuO NPs induced oxidative stress which decreased photosynthetic pigments and increased osmoprotectant (proline) accumulation and activity of antioxidant enzymes. But increased amount of proline content and antioxidant activity did not become effective enough to protect the plant from CuO NPs stress as evident from high MDA content at higher 
concentration. These results can be correlated with the cytological changes observed in root tips. ROS production and hence oxidative stress could be the causative factor for chromosomal aberrations observed in root tip cells. Thus, to become prudent towards the cytogenetic consequence of NPs to biotic systems it is essential to monitor their disposing management in the environment.

\section{Declarations}

Ethical approval and consent to participate- Ethical approval is not required for this manuscript. All authors were equally involved from experimentation to manuscript writing.

Consent for publication- It is declared that the publisher has the author's permission to publish the relevant contribution.

Availability of data and material- All the data of this manuscript has been compiled by entitled authors.

Conflict of interest- It is declared that no conflict of interest has been found.

Funding-Financial assistance has been provided by University Grant Commission (UGC), India. Grant No. is 788/(CSIR-UGC NET JUNE2017).

\section{Author's contribution-}

Vaibhav Kumar - Experimental Design, Data Compilation, Data analysis, First draft of manuscript Writing. Adiba Khan- Data Compilation and Statistical analysis.

Prof. Alka Srivastava- Cytogenetics expertise.

Prof. Gauri Saxena- Final editing and checking of the manuscript.

Dr. Praveen C. Verma - Elucidate the results

\section{Acknowledgement}

The authors are highly thankful for the financial assistance provided by University Grant Commission (UGC), India.

\section{References}

1. Arnon DI (1949) Copper enzyme polyphenoloxides in isolated chloroplast in Beta vulgaris. Plant Physiol 24:1-15

2. Auffan M, Rose J, Bottero JY, Lowry GV, Jolivet JP, Wiesner MR (2009) Towards a definition of inorganic nanoparticles from an environmental, health and safety perspective. Nat Nanotechnol 4:634-641. http://dx.doi.org/10.1038/nnano.2009.242 
3. Barillet S, Jugan ML, Laye M, Leconte Y, Herlin-Boime N, Reynaud C, Carriere M (2010) In vitro evaluation of SiC nanoparticles impact on A549 pulmonary cells: cyto-, genotoxicity and oxidative stress. Toxicol Lett 198(3):324-330. http://dx.doi.org/10.1016/j.toxlet.2010.07.009

4. Bates LS, Waldren RP, Teare ID (1973) Rapid determination of free proline for water stress studies. Plant Soil 39:205-207

5. Beauchamp C, Firdovich I (1971) Superoxide dismutase: improved assays and an assay applicable to acrylamide gels. Anal Biochem 44:276-287

6. Bowler C, Montagu TV, Inze D (1992) Superoxide dismutase and stress tolerance. Annu Rev PInat Physiol Plant Mol Boil 43:83-116

7. Bradford MM (1976) A rapid and sensitive method for the quantitation of microgram quantities of protein utilizing the principle of protein-dye binding. Anal Biochem 72(1-2):248-254.

8. Brøgger A (1982) The chromatid gap- a useful parameter in genotoxicology. Cytogenet Cell Genet 33:4-19. http://dx.doi.org/10.1159/000131720

9. Bystrzejewska-Piotrowska G, Golimowski J, Urban PL (2009) Nanoparticles: their potential toxicity, waste and environmental management. Waste manag 29:2587-

2595. https://doi.org/10.1016/j.wasman.2009.04.001

10. Carlberg I, Mannervik B (1985) Glutathione reductase. In: Meister, A. (Ed.), Methods in Enzymology. Academic Press, San Diego, California, pp 484-490

11. Carmona ER, García-Rodríguez A, Marcos R (2018) Genotoxicity of Copper and Nickel Nanoparticles in Somatic Cells of Drosophila melanogaster. J Toxicol 8. http://dx.doi.org/10.1155/2018/7278036

12. Castiglione MR, Giorgetti L, Geri C, Cremonini R (2011) The effects of nano-TiO2 on seed germination, development and mitosis of root tip cells of Vicia narbonensis L. and Zea mays L. J Nanopart Res 13:2443-2449. http://dx.doi.org/10.1007/s11051-010-0135-8

13. Chan KL, Hickson ID (2011) New insights into the formation and resolution of ultra-fine anaphase bridges. Semin Cell Dev Biol 22:906-912. http://dx.doi.org/10.1016/j.semcdb.2011.07.001

14. Chichiriccò G, Poma A (2015) Penetration and toxicity of nanomaterials in higher plants. Nanomaterials 5:851-73.

15. Chou $\mathrm{CH}$, Chiang YC, Khan, $\mathrm{Cl}$ (1978) Impact of water pollution on crop growth in Taiwan. Bot Bull Acad Sinica 19:107-124

16. Choudhary M, Jetley UK, Abash KM, Zutshi S, Fatma T (2007) Effectof heavy metal stress on proline, malondialdehyde, and superoxide dismutase activity in the cyanobacterium Spirulina platensis. Ecotoxicol Environ Saf 66:204-209

17. Cimini D, Fioravanti D, Salmon ED, Degrassi F (2002) Merotelic kinetochore orientation versus chromosome mono-orientation in the origin of lagging chromosomes in human primary cells. J Cell Sci 115:507-515

18. Colvin VL (2003) The potential environmental impact of engineered nanomaterials. Nat Biotechnol 21:1166-1170 
19. Costa MVJD, Sharma PK (2016) Effect of copper oxide nanoparticles on growth, morphology, photosynthesis, and antioxidant response in Oryzasativa. Photosynthetica 54:110-

119. http://dx.doi:org/10.1007/s11099-015-0167-5

20. Demir E, Kaya N, Kaya B (2014) Genotoxic effects of zinc oxide and titanium dioxide nanoparticles on root meristem cells of Allium cepa by comet assay. Turk J Biol 38:3139. http://dx.doi.org/10.3906/biy-1306-11

21. Dimkpa CO, McLean JE, Latta DE, Manangón E, Britt DW, Johnson WP, Boyanov BI, Anderson AJ (2012) $\mathrm{CuO}$ and $\mathrm{ZnO}$ nanoparticles: phytotoxicity, metal speciation, and induction of oxidative stress in sand-grown wheat. J Nanopart Res 14:1125. http://dx.doi.org/10.1007/s11051-012-1125-9

22. Dixon DP, Skipsey M, Edwards R (2010) Roles for glutathione transferases in plant secondary metabolism. Phytochemical 71:338-350

23. Euler HV, Josephson K (1927) Uber Catalase. I. Justus Liebigs Annalen Der Chemie 452:158-181

24. Fenech M, Krisch-Volders M, Natarajan AT, Surralles J, Crott JW, Parry J, Noppa H, Eastmond DA, Tucker JD, Thomas P (2011) Molecular mechanism of micronucleus, nucleoplasmic bridge and nuclear bud formation in mammalian and human cells. Mutagenesis 26:125-

132. http://dx.doi.org/10.1093/mutage/geq052

25. Freyer MJ, Oxborough K, Mullineaux PM, Baker NR (2002) Imaging of photo-oxidative stress responses in leaves. J Exp Bot 53:1249-1253

26. Fridovich I (1989) Superoxide dismutases. An adaptation to a paramagnetic gas. J Biol Chem 264:7761-7764

27. Ganguly P, Breen A, Pillai SC (2018) Toxicity of nanomaterials: exposure, pathways, assessment, and recent advances. ACS Biomater Sci Eng 4:2237-75

28. Gaulden ME (1987) Hypothesis: some mutagens directly alter specific chromosomal proteins (DNA topoisomerase II and peripheral proteins) to produce chromosome stickiness, which causes chromosome aberrations. Mutagenesis 2:357-365

29. Gill SS, Amjum NA, Hasanuzzaman M, Gill R, Trivedi DK, Ahmad I, Pereira E, Tuteja N (2013) Glutathion and glutathione reductase: a boon in disguise in plant abiotic stress defense operations. Plant Phydiol Biochem 70:204-212. http://dx.doi.org/10.1016/j.plaphy.2013.05.032

30. Gill SS, Tuteja N (2010) Reactive oxygen species and antioxidant machinery in abiotic stress tolerance in crop plants. Plant Physiol Biochem 48:909-930

31. Grigore ME, Biscu ER, Holban AM, Gestal MC, Grumezescu AM (2016) Methods of synthesis, properties and biomedical application of $\mathrm{CuO}$ nanoparticles. Pharmaceuticals

9:75. http://dx.doi.org/10.3390/ph9040075

32. Habig WH, Pabst, MJ, Jakoby WB (1974) Glutathione S-transferases. The first enzymatic step in mercapturic acid formation. J Biol Chem 249:7130-7139

33. Hashemi S (2019) Effect of Nanoparticles on Lipid Peroxidation in Plants. In Advances in Lipid Metabolism. IntechOpen. http://dx.doi.org/10.5772/intechopen.88202 
34. Hayat S, Hayat Q, Alyemeni MN, Wani AS, John Pichtel J, Ahmad A (2012) Role of proline under changing environments: A review, Plant Signal Behav 7:14561466. http://dx.doi.org/10.4161/psb.21949

35. Heath RL, Packer, L (1968) Photoperoxidation in isolated chloroplasts: I. Kinetics and stoichiometry of fatty acid peroxidation. Arch Biochem Biophys 125:189-198. http://doi.org/10.1016/00039861(68)90654-1

36. Hernández JA, Corpas FJ, Gómez M, del Río LA, Sevilla F (1993) Saltinduced oxidative stress mediated by activated oxygen species in pea leaf mitochondria. Physiol Plant 89:103-110

37. Huang Y, Wu C, Aronstam R (2010) Toxicity of transition metal oxide nanoparticles: recent insights from in vitro Studies. Materials 3:4842-4859

38. Itani R, Tobaiqy M, Al Faraj A (2020) Optimizing use of theranostic nanoparticles as a life-saving strategy for treating COVID-19 patients. Theranostics 10:5932-

5942. http://dx.doi.org/10.7150/thno.46691

39. Jammi S, Sakthivel S, Rout L, Mukherjee T, Mandal S, Mitra R, Saha P, Punniyamurthy T, (2009) CuO nanoparticles catalyzed $\mathrm{C}-\mathrm{N}, \mathrm{C}-\mathrm{O}$, and $\mathrm{C}-\mathrm{S}$ cross coupling reactions: scope and mechanism. $\mathrm{J}$ Org Chem 74:1971-1976

40. Jing-Jing Y (2011) Study on organic wastewater monitoring of laboratory using mon test of Vicia faba root tips. J Anhui Agric Sci 17. http://en.cnki.com.cn/Article_en/CJFDTotalAHNY201117118.htm

41. Jośko I, Oleszczuk P, Skwarek E (2017) Toxicity of combined mixtures of nanoparticles to plants. J Hazard Mater 331:200-209

42. Kah M (2015) Nanopesticides and nanofertilizers: emerging contaminants or opportunities for risk mitigation? Front Chem 3:64. http://dx.doi.org/10.3389/fchem.2015.00064

43. Kahru A, Dubourguier HC (2010) From ecotoxicology to nanoecotoxicology. Toxicology 269:105-119

44. Keller AA, Mc Ferran S, Lazareva A, Suh S (2013) Global life cycle releases of engineered nanomaterials. J Nanopart Res 15:1-17. http://dx.doi.org/10.1007/s11051-013-1692-4

45. Khan A, Kumar V, Srivastava A, Saxena G, Verma PC (2021) Biomarker-based evaluation of cytogenotoxic potential of glyphosate in Vigna mungo (L.) Hepper genotypes. Environ Monit Assess 193(2):1-13. https://doi.org/10.1007/s10661-021-08865-x

46. Khan Z, Ansari MYK (2018) Impact of engineered Si nanoparticles on seed germination, vigour index and genotoxicity assessment via DNA damage of root tip cells in Lens culinaris. J Plant Biochem Physiol 6:2. http://dx.doi.org/10.4172/2329-9029.1000218

47. Khan Z, Ansari MYK, Gupta H, Choudhary S (2009) Dynamics of 2, 4-D in generation of cytomorphological variants in an important anticancerous and antihepatotoxic herb Cichorium intybus L. Turk J Bot 3:383-387

48. Kisin ER, Murray AR, Keane MJ, Shi XC, Schwegler-Berry D, Gorelik O, Arepalli S, Castranova V, Wallace WE, Kagan VE, Shvedova AA (2007) Single-walled carbon nanotubes: geno and cytotoxic 
effects in lung fibroblast V79 cells. J Toxicol Environ Health Part A 70:2071-2079

49. Klębowski B, Depciuch J, Parlińska-Wojtan M, Baran J (2018) Applications of noble metal-based nanoparticles in medicine. Int J Mol Sci 19:4031

50. Lazareva A, Keller AA (2014) Estimating potential life cycle releases of engineered nanomaterials from wastewater treatment plants. ACS Sustain Chem Eng 2:16561665. http://dx.doi.org/10.1021/sc500121w

51. Li X, Ke M, Zhang M, Peijnenburg WJ, Fan X, Xu J, Zhang Z, Lu T, Fu Z, Qian H (2018) The interactive effects of diclofop-methyl and silver nanoparticles on Arabidopsis thaliana: growth, photosynthesis and antioxidant system. Environ Pollut 232:212-219

52. Liang XJ, Chen C, Zhao Y, Jia L, Wang PC (2008) Biopharmaceutics and therapeutic potential of engineered nanomaterials. Curr Drug Metab 9:697-709

53. Liu J, Yi HL (2007) Cytogenetic damage induced by sulphur dioxide in Vicia faba root and leaf meristematic cells. http://en.cnki.com.cn/Article_en/CJFDTOTAL-MBZW200706021.htm

54. Loza K, Diendorf J, Sengstock C, Ruiz-Gonzalez L, Gonzalez-Calbet JM, Vallet-Regi M, Köller M, Epple $M$ (2014) The dissolution and biological effects of silver nanoparticles in biological media. J of Mater Chemi B. 2(12):1634-43

55. Luck H (1963) Peroxidase. Bergmeyer HU 1965. Methods of enzymatic analysis. Academic Press Inc, New York, pp 895-897

56. Lutterbeck CA, Kern DI, Machado EL, Kümmerer K (2015) Evaluation of the toxic effects of four anticancer drugs in plant bioassays and its potency forscreening in the context of waste water reuse for irrigation. Chemosphere 135:403-410

57. Magdolenova Z, Collins A, Kumar A, Dhawan A, Stone V, Dusinska M (2014) Mechanisms of genotoxicity. A review of in vitro and in vivo studies with engineered nanoparticles. Nanotoxicology 8:233-278. http://dx.doi.org/10.3109/17435390.2013.773464

58. Mangalampalli B, Dumala N, Grover P (2017) Allium cepa root tip assay in assessment of toxicity of magnesium oxide nanoparticles and microparticles. J Environ Sci 66:125-

137. http://dx.doi.org/10.1016/j.jes.2017.05.012

59. Manke A, Wang L, Rojanasakul Y (2013) Mechanisms of nanoparticle-induced oxidative stress and toxicity. Biomed Res Int e942916. http://dx.doi.org/10.1155/2013/942916

60. Maynard AD (2007) Nanotechnology: the next big thing, or much ado about nothing? Ann Occup Hyg 51:1-12

61. Miralles P, Church TL, Harris AT (2012) Toxicity, uptake, and translocation of engineered nanomaterials in vascular plants. Environ Sci Technol 46:9224-9239

62. Mirzajani F, Askari H, Hamzelou S, Farzaneh M, Ghassempour A (2013) Effect of silver nanoparticles on Oryza sativa L. and its rhizosphere bacteria. Ecotoxicol Environ Saf 88:4854. http://dx.doi.org/10.1016/j.ecoenv.2012.10.018 
63. Nair PGM, Chung IM (2014) Impact of copper oxide nanoparticles exposure on Arabidopsis thaliana growth, root system development, root lignificaion, and molecular level changes. Environ Sci Pollut Res 21:12709-12722. http://dx.doi.org/10.1007/s11356-014-3210-3

64. Nair R, Varghese SH, Nair BG, Maekawa T, Yoshuda Y, Kumar DS (2010) Nanoparticulate material delivery to plants. Plant Sci 179:154-1643

65. Nasrollahi N, Aber S, Vatanpour V, Mahmoodi NM (2019) Development of hydrophilic microporous PES ultrafiltration membrane containing $\mathrm{CuO}$ nanoparticles with improved antifouling and separation performance. Mater Chem Phys 222:338-350

66. Nekrasovaa GF, Ushakovaa OS, Ermakovb AE, Uiminb MA, Byzovb IV (2011) Effects of Copper (II) Ions and Copper Oxide Nanoparticles on Elodea densa Planch. Russian Journal of Ecology 42:458463

67. Ochoa L, Medina-Velo IA, Barrios AC, Bonilla-Bird NJ, Hernandez-Viezcas JA, Peralta-Vedea JR, Gardea-Torresdey JL (2017) Modulation of CuO nanoparticles toxicity to green pea (Pisum sativum Fabaceae) by the phytohormone indile-3-acetic acid. Sci Total Environ 598:513-524

68. Oliveira ML, Izquierdo M, Querol X, Lieberman RN, Saikia BK, Silva LF (2019) Nanoparticles from construction wastes: A problem to health and the environment. J Clean Prod 219:236243. https://doi.org/10.1016/j.jclepro.2019.02.096

69. Pakrashi S, Jain N, Dalai S, Jayakumar J, Chandrasekaran PT, Raichur AM, Chandrasekaran N, Mukherjee A (2014) In vivo genotoxicity assessment of titanium dioxide nanoparticles by Allium cepa root tip assay at high exposure concentrations. PLoS ONE 9: e87789. http://dx.doi.org/10.1371/journal.pone.0087789

70. Patlolla AK, Berry A, May L, Tchounwou PB (2012) Genotoxicity of silver nanoparticles in Vicia faba: a pilot study on the environmental monitoring of nanoparticles. Int J Environ Res Public Health 9:1649-1662. http://dx.doi.org/10.3390/ijerph9051649

71. Prajitha N, Athira SS, Mohanan PV (2019) Bio-interactions and risks of engineered nanoparticles. Environ Res 172:98-108

72. Radad K, Al-Shraim M, Moldzio R, Rausch WD (2012) Recent advances in benefits and hazards of engineered nanoparticles. Environ Toxicol Pharmacol 34:661672. http://dx.doi.org/10.1016/j.etap.2012.07.011

73. Rastogi A, Tripathi DK, Yadav S, Chauhan DK, Živčák M, Ghorbanpour M, El-Sheery NI, Brestic M (2019) Application of silicon nanoparticles in agriculture. 3 Biotech 9(3):1-11

74. Rastogi A, Zivcak M, Sytar O, Kalaji HM, He X, Mbarki S, Brestic M (2017) Impact of Metal and Metal Oxide Nanoparticles on Plant: A Critical Review. Front Chem

5:78. http://dx.doi.org/10.3389/fchem.2017.00078

75. Redli PM, Gasic I, Meraldi P, Nigg EA, Santamaria A (2016) The Ska complex promotes Auroa B activity to ensure chromosomes biorientation. J Cell Biol 215:77-

93. http://dx.doi.org/10.1083/jcb.201603019 
76. Savage JR, (2004) On the nature of visible chromosomal gaps and breaks. Cytogenet. Genome Res. 104:46-55

77. Sengul AB, Asmatulu E (2020) Toxicity of metal and metal oxide nanoparticles: a review. Environ Chem Lett 18:1659-1683. https://doi.org/10.1007/s10311-020-01033-6

78. Servin A, Elmer W, Mukherjee A, De La Torre-Roche R, Hamdi H, White JC, Dimpka C (2015) Nanoscale micronutrient suppress disease. VFRC Report 2015/2. Virtual Fertilizer Research Centre, Washington, D.C., pp 33

79. Sharma A, Wang J, Xu D, Tao S, Chong S, Yan D, Li Z, Yuan H, Zheng B (2020) Melatonin regulates the functional components of photosynthesis, antioxidant system, gene expression, and metabolic pathways to induce drought resistance in grafted Carya cathayensis plants. Sci Tot Environ 713:1366-1375

80. Sharma AK, Sharma A (1980) Chromosome Techniques: Theory and Practice, 3rd. Butterworths and Co. Ltd, London

81. Shaw Ak, Hossain Z (2013) Impact of nano-CuO stress on rice (Oryza sativa L.) seedlings. Chemosphere 93:906-915. http://dx.doi.org/10.1016/j.chemosphere.2013.05.044

82. Shi J, Peng C, Yang Y, Yang J, Zhang H, Yuan X, Chen Y, Hu T (2014) Phytotoxicity and accumulation of copper oxide nanoparticles to the Cu-tolerant plant Elsholtzia splendens. Nanotoxicol 8:179188. http://dx.doi.org/10.3109/17435390.2013.766768

83. Silveira GL, Lima MGF, Reis GBD, Palmieri MJ, Vieria LFA (2017) Toxic effects of environmental pollutants: comparative investigation using Allium cepa L. and Lactuca sativa L. Chemosphere 178:359-367. http://dx.doi.org/10.1016/j.chemosphere.2017.03.048

84. Song G, Hou W, Gao Y, Wang Y, Lin L, Zhang Z, Niu Q, Ma R, Mu L, Wang H (2016) Effects of CuO nanoparticles on Lemna minor. Bot Stud 57:1-8. http://dx.doi.org/10.1186/s40529-016-0118-x

85. Stephenson C, Hubler A (2015) Stability and conductivity of self assembled wires in a transverse electric field. Sci Rep 5:1-9. http://dx.doi.org/10.1038/srep15044

86. Tatum TC, Rayburn AL (2006) PRINC-labeled knobs are not associated with increased chromosomal stickiness in the maize st 1 mutant. J Hered 97:417-422

87. Topaktas M, Renciizogullar E (1993) Chromosomal aberrations in cultured human lymphocytes treated with Marshal and its effective ingredient Carbosulfan. Mutat Res 319:103-111

88. Townsend D, Tew K (2003) The role of glutathione s-transferase in anti cancer drug resistance. Oncogene 22:7369-7375. http://dx.doi.org/10.1038/sj.onc.1206940

89. Vaziri MR, Omidvar A, Jaleh B, Shabestari NP (2017) Investigating the extrinsic size effect of palladium and gold spherical nanoparticles. Optic Mater. 64:413-

20. http://dx.doi.org/10.1016/j.optmat.2017.01.014

90. Vert M, Doi Y, Hellwich KH, Hess M, Hodge P, Kubisa P, Rinaudo M, Schué FO (2012) Terminology for biorelated polymers and applications (IUPAC Recommendations 2012). Pure App/ Chem 84:377410. http://dx.doi.org/10.1351/PAC-REC-10-12-04 
91. Wan J, Wang R, Wang R, Ju Q, Wang Y, Xu J (2019) Comparative physiological and transcriptomic analyses reveal the toxic effects of $\mathrm{ZnO}$ nanoparticles on plant growth. Environ Science Technol 53(8):4235-44

92. Wen S, Yingxiang D, Jianqiu C, Junping K, Boyang Y (2009) Interaction between titanium dioxide nanoparticles and human serum albumin revealed by fluorescence spectroscopy in the absence of photoactivation. J Lumin 129:778-783. http://dx.doi.org/10.1016/j.jlumin.2009.02.010

93. Wise RR (1995) Chilling enhanced photo-oxidation: the production, action and study of reactive oxygen speciese produced during chilling in the light. Photosynth Res 45:79-97

94. Xia J, Zhao HZ, Lu GH (2013) Effects of selected metal oxide nanoparticles on multiple biomarkers in Carassius auratus. Biomed Environ Sci 26:742-749

95. Zhao L, Lu L, Wang A, Zhang H, Huang M, Wu H, Xing B, Wang Z, Ji R (2020) Nano-biotechnology in agriculture: use of nanomaterials to promote plant growth and stress tolerance. J Agric Food Chem 68(7):1935-1947

96. Ziental D, Czarczynska-Goslinska B, Mlynarczyk DT, Glowacka-Sobotta A, Stanisz B, Goslinski T, Sobotta L (2020) Titanium dioxide nanoparticles: prospects and applications in medicine. Nanomaterials 10(2):387. https://doi.org/10.3390/nano10020387

\section{Tables}

Table 1 Effect of different concentrations of CuO NPs and BPs on MI (\%) of $V$. faba var. Pusa Sumit.

\begin{tabular}{|c|c|c|c|c|c|c|c|c|}
\hline $\begin{array}{l}\text { Conc. } \\
\left(\mathrm{mg} \mathrm{L} \square^{1}\right)\end{array}$ & & $\begin{array}{l}\text { Total } \\
\text { Cells }\end{array}$ & $\begin{array}{l}\text { Dividing } \\
\text { Cells }\end{array}$ & $\begin{array}{l}\text { Prophase } \\
\text { (\%) }\end{array}$ & $\begin{array}{l}\text { Metaphase } \\
(\%)\end{array}$ & $\begin{array}{l}\text { Anaphase } \\
(\%)\end{array}$ & $\begin{array}{l}\text { Telophase } \\
\text { (\%) }\end{array}$ & $\begin{array}{l}\text { MI (\%) } \\
\mathrm{AM} \pm \mathrm{SE}\end{array}$ \\
\hline Control & & 1240 & 422 & 26.12 & 2.90 & 3.22 & 1.77 & $\begin{array}{l}34.02 \pm \\
0.62\end{array}$ \\
\hline NPs 20 & & 1228 & 382 & 24.18 & 2.85 & 2.93 & 1.14 & $\begin{array}{l}31.11 \pm \\
0.91\end{array}$ \\
\hline 40 & & 1189 & 309 & 18.92 & 3.02 & 3.02 & 1.85 & $\begin{array}{l}26.02 \pm \\
1.1\end{array}$ \\
\hline 60 & & 1173 & 223 & 12.10 & 2.47 & 3.06 & 1.36 & $\begin{array}{l}19.12 \pm \\
0.94\end{array}$ \\
\hline 80 & & 1149 & 139 & 8.70 & 1.82 & 1.91 & 0.78 & $\begin{array}{l}12.09 \pm \\
0.76\end{array}$ \\
\hline 100 & BPs & 1075 & 107 & 9.95 & 1.67 & 2.23 & 0.65 & $9.98 \pm$ \\
\hline 20 & & 1227 & 409 & 26.97 & 2.93 & 3.01 & 1.46 & 0.57 \\
\hline 40 & & 1218 & 389 & 24.87 & 2.79 & 2.87 & 1.47 & $33.33 \pm$ \\
\hline 60 & & 1190 & 357 & 22.94 & 2.85 & 2.52 & 1.68 & 0.75 \\
\hline 80 & & 1172 & 304 & 19.28 & 2.73 & 2.47 & 1.45 & $31.93 \pm$ \\
\hline 100 & & 1137 & 243 & 16.09 & 2.28 & 1.93 & 1.05 & 0.89 \\
\hline & & & & & & & & $30 \pm 0.95$ \\
\hline & & & & & & & & $25.93 \pm$ \\
\hline & & & & & & & & 0.98 \\
\hline & & & & & & & & $21.37 \pm$ \\
\hline & & & & & & & & 0.78 \\
\hline
\end{tabular}


Table 2 Types of aberration (\%) and total chromosomal aberration (\%) as observed for different concentrations of CuO NPs and BPs in $V$. faba var. Pusa Sumit.

\begin{tabular}{rllllllllllll}
\hline $\begin{array}{l}\text { Conc } \\
\left(\mathrm{mg} \mathrm{L} \mathrm{q}^{1}\right)\end{array}$ & Frag & Stic & Clum & Prec & Diag & Brid & Lagg & C-mito & C- Gap & Spin dis & Mul. A & CA \pm SE \\
\hline NPs 20 & 0.32 & 0.24 & 0.16 & 0.24 & 0.32 & 0 & 0.16 & 0.08 & 0.08 & 0.32 & 0 & $1.93 \pm 0.38$ \\
40 & 0.50 & 0.42 & 0.50 & 0.33 & 0.42 & 0.25 & 0.33 & 0.16 & 0.16 & 0.33 & 0 & $3.45 \pm 0.38$ \\
60 & 0.76 & 0.68 & 0.51 & 0.51 & 0.42 & 0.34 & 0.42 & 0.34 & 0.17 & 0.59 & 0 & $4.89 \pm 0.45$ \\
80 & 0.87 & 0.78 & 0.69 & 0.52 & 0.60 & 0.52 & 0.69 & 0.52 & 0 & 0.69 & 0.17 & $6.07 \pm 0.35$ \\
100 & 0.93 & 1.02 & 1.20 & 0.65 & 0.74 & 0.65 & 0.83 & 0.74 & 0 & 0.83 & 0.18 & $7.85 \pm 0.54$ \\
BPs 20 & 0 & 0.24 & 0 & 0.08 & 0.16 & 0 & 0 & 0.16 & 0 & 0.24 & 0 & $0.89 \pm 0.23$ \\
40 & 0.16 & 0.25 & 0 & 0.16 & 0.24 & 0 & 0.08 & 0.16 & 0.08 & 0.33 & 0 & $1.47 \pm 0.37$ \\
60 & 0.25 & 0.35 & 0.17 & 0.35 & 0.25 & 0.08 & 0.16 & 0.25 & 0.08 & 0.50 & 0 & $2.43 \pm 0.31$ \\
80 & 0.17 & 0.34 & 0.43 & 0.42 & 0.34 & 0.17 & 0.34 & 0.26 & 0.26 & 0.59 & 0 & $3.32 \pm 0.42$ \\
100 & 0.35 & 0.26 & 0.62 & 0.53 & 0.44 & 0.35 & 0.61 & 0.52 & 0.18 & 0.35 & 0.09 & $4.30 \pm 0.33$ \\
\hline
\end{tabular}

Frag fragmentation, Stic stickiness, Clum clumping, Pre precocious, Diag diagonal anaphase, Brid bridge, Lag laggard, C-mito c-mitosis, C-gap chromosome gap, Spin dis spindle disorientation, Mult A multiple aberration, CA chromosomal aberration

\section{Figures}



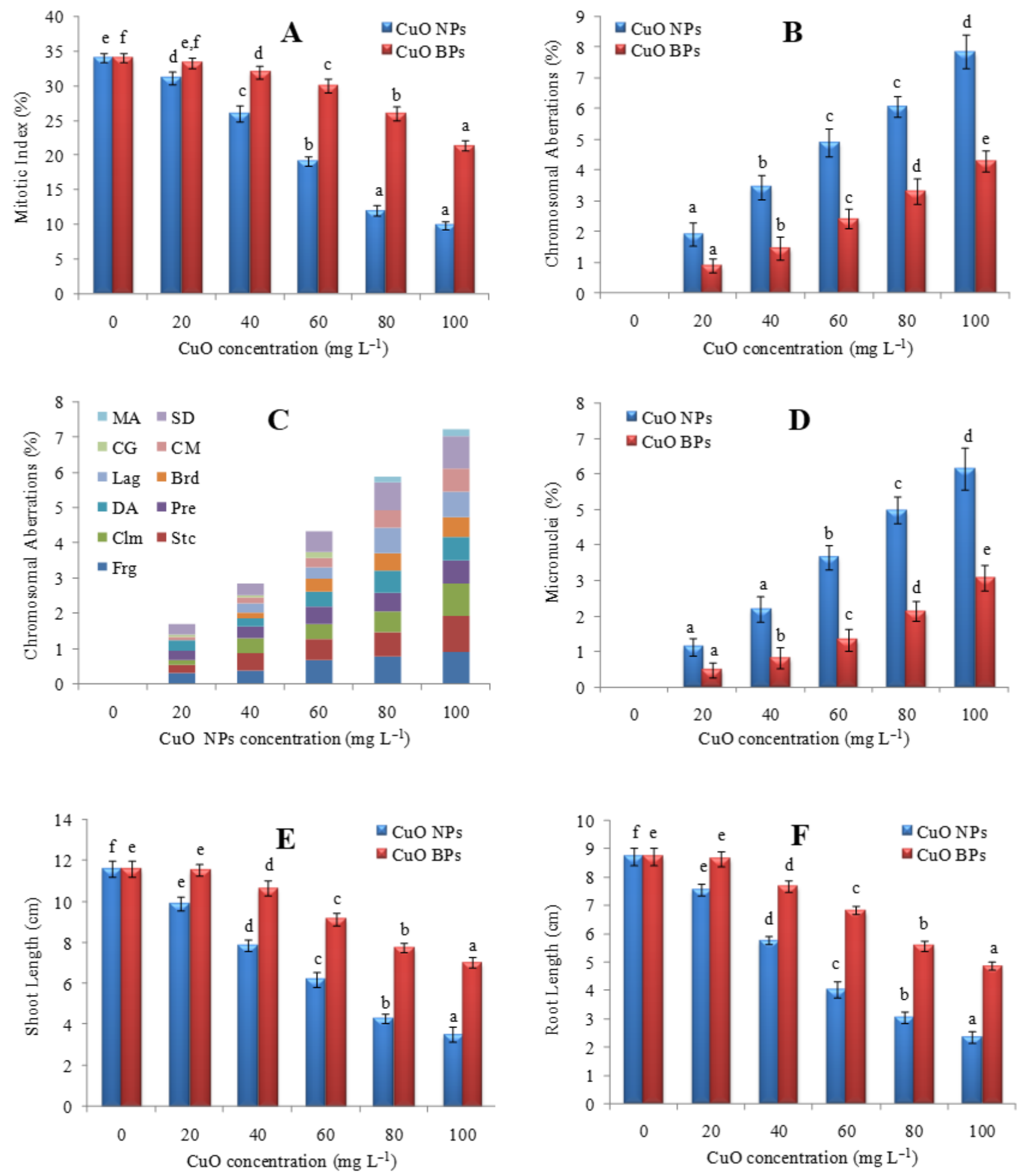

\section{Figure 1}

Graphical presentation of the effect of CuO NPs and BPs on MI (A), CAs (B, C), Micronuclei formation (D), shoot length (E), and root length ( $F)$ in V. faba var. Pusa Sumit. (MA: Multiple aberrations; CG:

Chromosome gap; Lag: Laggard; DA: Disoriented Anaphase; Clm: Clumping; Frag: Fragmentation; SD:

Spindle Disorientation; CM: C-Metaphase; Brd: Bridge; Pre: Precocious; Stc: Stickiness) Different 
superscripts viz. a, b, c, d, e, and f show the significant differences as analyzed by one-way ANOVA followed by DMRT $(P \leq 0.05)$.
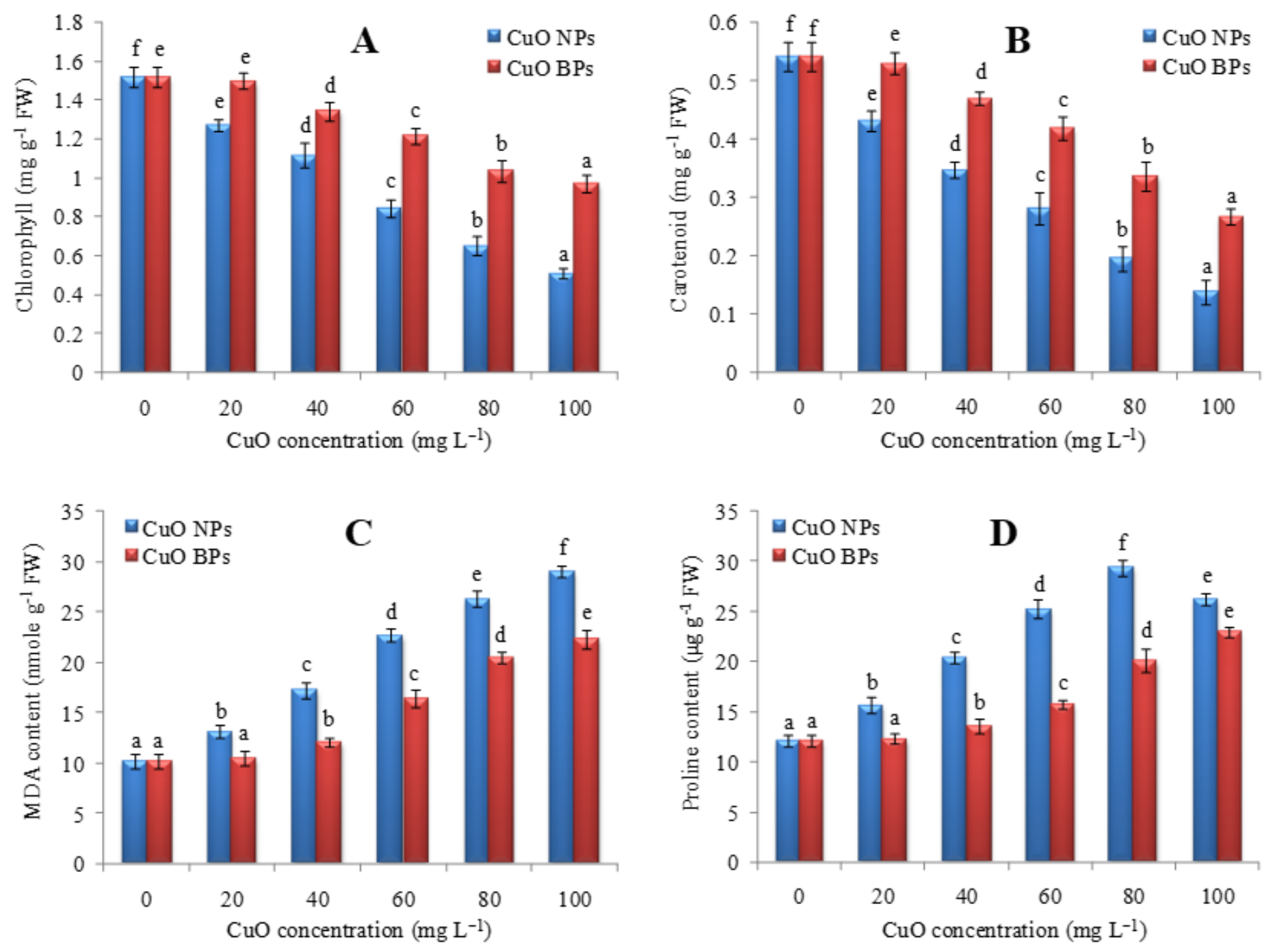

Figure 2

Graphical presentation of the effect of CuO NPs and BPs on chlorophyll (A) carotenoids (B), MDA content (C), and proline content (D) in V. faba var. Pusa Sumit. Different superscripts viz. a, b, C, d, e, and f show significant differences as analyzed by one-way ANOVA followed by DMRT $(P \leq 0.05)$. 

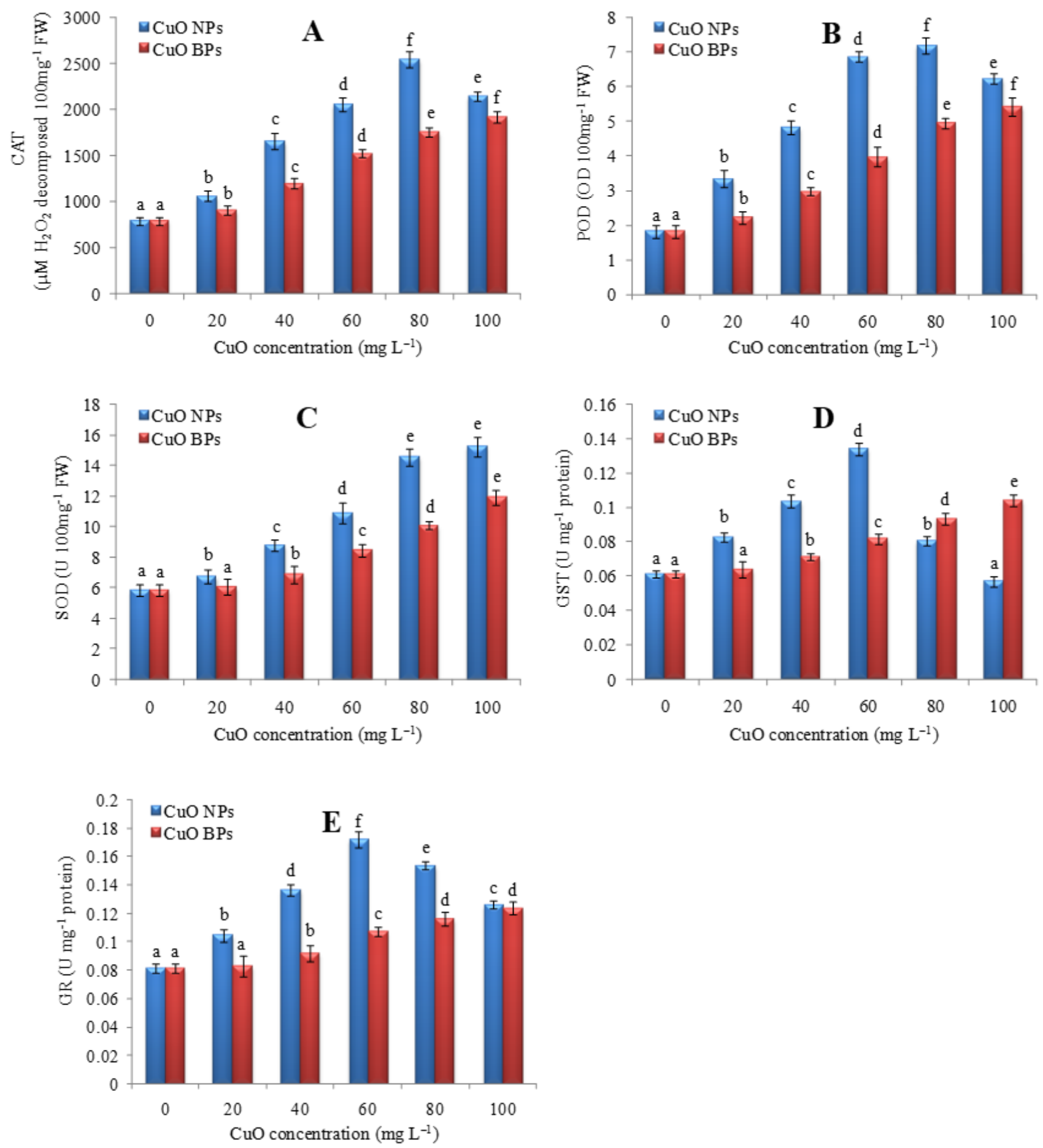

Figure 3

Graphical presentation of the effect of CuO NPs and BPs on activities of CAT (A), POD (B), SOD (C), GST (D), and GR (E) in V. faba var. Pusa Sumit. Different superscripts viz. $a, b, c, d$, e and f show significant differences as analyzed by one-way ANOVA followed by DMRT $(P \leq 0.05)$. 

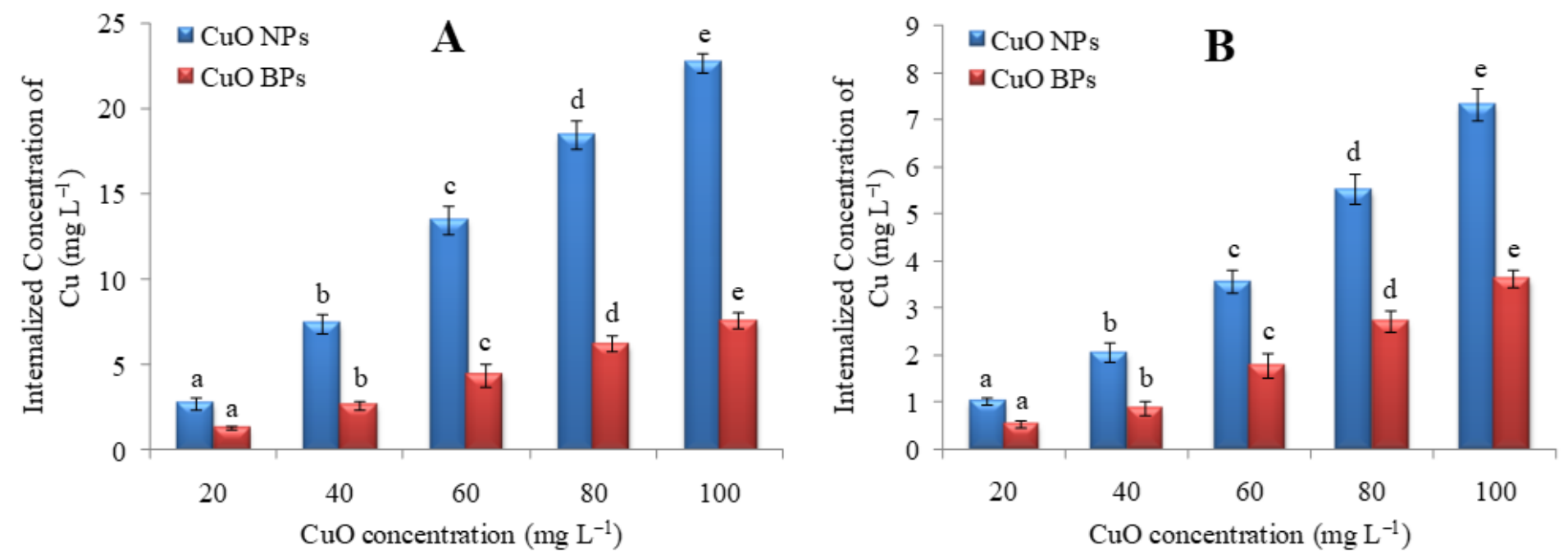

Figure 4

Representation of normal mitotic phases and chromosomal aberrations in V. faba var. Pusa Sumit against exposure of CuO NPs: (A) prophase (B) metaphase (C) anaphase (D) telophase (E) Chromosome gap $(\mathrm{F})$ sticky metaphase $(\mathrm{G})$ C-metaphase $(\mathrm{H})$ diagonal anaphase $(\mathrm{I})$ precocious chromosome $(\mathrm{J})$ laggard $(K)$ anaphase bridge $(L)$ fragments $(M)$ spindle disorientation $(N)$ clumped telophase $(O)$ multiple aberrations- bridge and laggard $(P)$ micronucleus. 

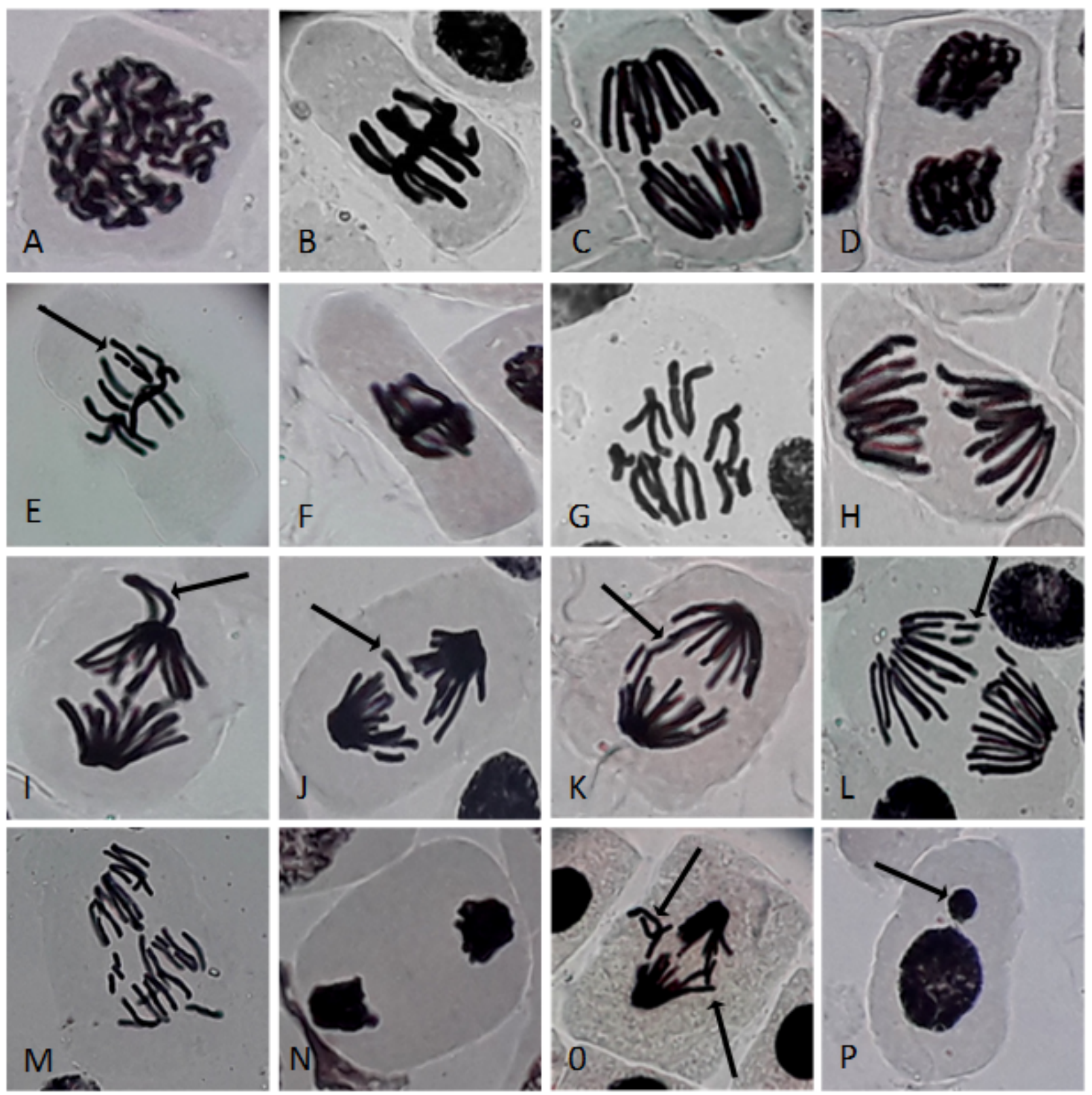

Figure 5

Internalization of CuO NPs and BPs into the roots and leaves as analyzed by ICP-OES.

\section{Supplementary Files}

This is a list of supplementary files associated with this preprint. Click to download.

- Supplementaryfile.docx 